\title{
Detection and Monitoring of Carbon Monoxide (Co) Toxic Gases in Old Vehicle Cabin (Odometer> 300k Km) and Its Relationship to Vehicle Density Using Fuzzy Method
}

\author{
Suzuki Syofian ${ }^{1 *}$, Aji Setiawan ${ }^{1}$, Rolan Siregar ${ }^{1}$, Muhamad Fathan $^{1}$ \\ ${ }^{I}$ Department Information of Technology Darma Persada University \\ ${ }^{*}$ Corresponding author. Email: Suzuki_syofian@ft.unsada.ac.id
}

\begin{abstract}
Carbon monoxide (CO) gas in the cabin of a vehicle affects the health of passengers and can even cause death. This is caused by poor ventilation so that the exhaust that leaks into the car and is slowly inhaled by the person in the car. Carbon monoxide is an odorless, colorless, tasteless and non-irritating gas. Carbon monoxide gas is a material commonly found in industry. This gas is the result of incomplete combustion from motorized vehicles, heating devices, equipment that uses carbon-based fire materials and flames (such as wood stoves), smoke from trains, gas combustion, and tobacco smoke. However, the most common source is engine combustion residue.Based on these problems, it is necessary to do research on the engineering of a control device for carbon monoxic gas levels in a car cabin based on fuzzy logic. In this research, a microcontroller will be used to carry out the process. With this tool, it is hoped that carbon monoxide levels will be obtained in the car so that it can notify drivers. In the end, cases of poisoning by passengers due to $\mathrm{CO}$ gas in vehicles can be minimized.
\end{abstract}

\section{Keywords: Toxic Gases, Fuzzy Method, Odometer, Carbon Monoxide}

\section{INTRODUCTION}

Older vehicles are more likely to produce more toxic gas emissions due to incomplete combustion systems. This gas is very dangerous because it can cause health problems even at a more severe level, it is the cause of human death [1][2]. Many cases of sudden death are caused by this gas, especially in four-wheeled vehicle users.

The exhaust gas in the vehicle is the residue from combustion in the form of water (H2O), Carbon Monoxide (CO), Carbon Dioxide (CO2), Nitrogen Oxide (NO), Sulfur Dioxide (SO2) and Hydrate Carbon (HC) compounds as imperfect combustion processes and loose particles [2]. In old age vehicles, leakage problems from the $\mathrm{AC}$ system are common [3] [4]. If incomplete combustion occurs and will produce $\mathrm{CO}$ gas, the gas will enter through the leaky AC (Air Conditioner) hole [5]. In addition, the adhesive rubber on the car door that has shrunk and the joints of some parts that are not perfectly adhered are often the source of the entry of toxic emission gases into the car cabin. In some cases many passengers tend not to know for sure that the vehicle contains a lot of carbon monoxide gas, because it is colorless, smelly, and tastes.

The presence of $\mathrm{CO}$ gas will be very dangerous if inhaled by humans because the gas will replace the position of oxygen related to hemoglobin in the blood. $\mathrm{CO}$ gas will flow into the heart, brain and vital organs. The bond between $\mathrm{CO}$ and hemoglobin forms a carboxy hemoglobin which is 200 times stronger than the bond between oxygen and hemoglobin. The results were fatal. First, oxygen will be unable to compete with $\mathrm{CO}$ when it binds to the hemoglobin molecule. This means that the oxygen level in the blood will decrease. Even though it is known that oxygen is needed by the body's cells and tissues to carry out metabolic functions. Second, $\mathrm{CO}$ gas will inhibit the cytochrome oxidation complex. This makes intracellular respiration less effective. Finally, $\mathrm{CO}$ can bind directly to heart muscle cells and bones. The most serious effect is direct poisoning of 
these cells, as well as causing disorders of the nervous system.

The main danger to health is causing blood disorders, the limit of carbon monoxide exposure allowed by OSHA (Occupational Safety and Health Administration) is $35 \mathrm{ppm}$, while that allowed by BSN (National Standard Agency) is $25 \mathrm{ppm}$ where there are workers who can be exposed chemicals daily for no more than 8 hours per day or 40 hours per week. Levels that are considered to be immediately harmful to life or health are $1500 \mathrm{ppm}$ $(0.15 \%)$. Exposure of $1000 \mathrm{ppm}(0.1 \%)$ for several minutes can cause $50 \%$ saturation of the carboxy hemoglobin and can be fatal.

\section{METHODS}

The research method starts from the stage of making the flow chart of the system to be built, the research stages as shown in Figure 1. Furthermore, the data collection is carried out by looking for the average data, data before processing is in the form of sensor measuring instrument data that records $\mathrm{CO}$ levels every 2 minutes once in 1 hour. 12 minutes. So in a day there are 36 times the CO pollution data recorded. The following is the output of the MQ 7 tool used to detect vehicles that are under 5 years old and vehicles over 5 years old.

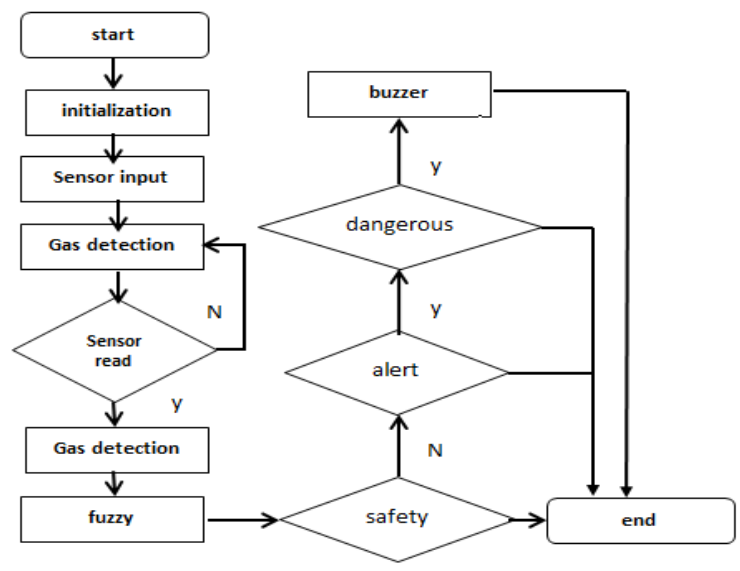

Figure 1. Flow diagram.

The data used is the data from the measuring device for the $\mathrm{CO}$ content sensor in vehicles under 5 years old and vehicles over 5 years old. Data is taken within 2 days, data is taken for vehicles under 5 years of age at 18 to 21 at night, and data is taken for vehicles over 5 years of age at 18 at 21 at night. The data collected will then be searched for the possible hazard values using the fuzzy method. The fuzzy logic method workflow process can be explained as follows:
1. Fuzzification is the process of converting crisp input into fuzzy input, which is a linguistic value that is determined based on a certain membership function.

2. Interference is reasoning using fuzzy input and predefined fuzzy rules to produce fuzzy output.

3. Defuzzification is changing the output function to a crisp value based on a predetermined membership function.

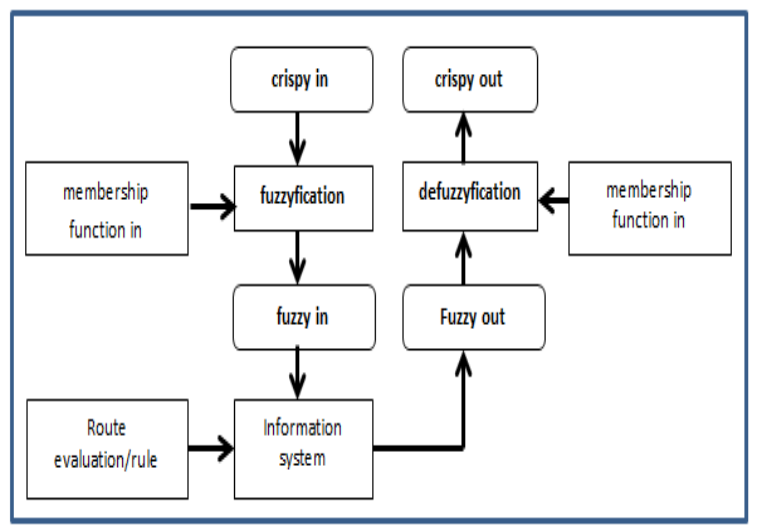

Figure 2. Fuzzy Logic Flow.

\section{RESULTS AND DISCUSSION}

\subsection{Testing the MQ7 Gas Sensor}

Testing at this stage uses a vehicle that is more than 5 years of use as a source of carbon monoxide gas. In this test, the measurements were carried out 36 times on the same car in 2 days. Data before processing is in the form of sensor measuring instrument data that records $\mathrm{CO}$ levels every 2 minutes. The data used is the data from the measuring device for the $\mathrm{CO}$ content sensor in vehicles under 5 years old and vehicles over 5 years old in a healthy and unhealthy condition. Data is taken for vehicles under 5 years old at 18 to 21 at night, and data is taken for vehicles over 5 years old at 18 at 21 at night. In the data collection process, the average data search was carried out. To find an error or the difference between the vehicle when the fan is off and the vehicle when the fan starts using equation 1.

\section{Error $=$}

fan measurement result in off condition measurement result in on

After calculating the error, what must be done is to calculate the average error using equation 2 and the percentage error in equation 3. Calculate the average error using the formula:

$$
\begin{gathered}
\text { ave error }=\frac{\text { number err in the exp }}{\text { number of measurement taken }} \\
\quad \% \text { error }=\frac{\text { ave error }}{100}
\end{gathered}
$$


Table 1 is the result of testing of $\mathrm{CO}$ gas measurements that have been carried out.

Table 1. Gas CO measurements result.

\begin{tabular}{|c|c|c|c|}
\hline Trial & Fan Off & Fan On & Error \\
\hline 1 & 13 & 15 & 2 \\
\hline 2 & 13 & 16 & 3 \\
\hline 3 & 14 & 14 & 0 \\
\hline 4 & 12 & 15 & 3 \\
\hline 5 & 13 & 14 & 1 \\
\hline 6 & 14 & 14 & 0 \\
\hline 7 & 13 & 12 & 1 \\
\hline 8 & 13 & 14 & 1 \\
\hline 9 & 20 & 14 & 6 \\
\hline 10 & 11 & 14 & 3 \\
\hline 11 & 9 & 14 & 5 \\
\hline 12 & 11 & 13 & 2 \\
\hline 13 & 12 & 15 & 3 \\
\hline 14 & 13 & 13 & 0 \\
\hline 15 & 15 & 13 & 2 \\
\hline 16 & 14 & 13 & 1 \\
\hline 17 & 13 & 13 & 0 \\
\hline 18 & 14 & 13 & 1 \\
\hline 19 & 15 & 13 & 2 \\
\hline 20 & 17 & 14 & 3 \\
\hline 21 & 10 & 13 & 3 \\
\hline 22 & 15 & 12 & 3 \\
\hline 23 & 15 & 12 & 3 \\
\hline 24 & 16 & 12 & 4 \\
\hline 25 & 16 & 11 & 5 \\
\hline 26 & 15 & 12 & 3 \\
\hline 27 & 15 & 11 & 4 \\
\hline 28 & 16 & 11 & 5 \\
\hline 29 & 16 & 11 & 5 \\
\hline 30 & 16 & 11 & 5 \\
\hline 31 & 16 & 12 & 4 \\
\hline 32 & 16 & 12 & 4 \\
\hline 33 & 16 & 10 & 6 \\
\hline 34 & 16 & 11 & 5 \\
\hline 35 & 15 & 12 & 3 \\
\hline 36 & 15 & 11 & 4 \\
\hline \multicolumn{3}{|l|}{ Total } & 93 \\
\hline
\end{tabular}

\begin{tabular}{|l|c|}
\hline Average error & 2,91667 \\
\hline Percentage of errors & 0,029 \\
\hline
\end{tabular}

3.2. Overall System Testing

Table 2. Overall tool test result.

\begin{tabular}{|c|c|c|c|}
\hline Trial & Fan Off & Fan On & Condition \\
\hline 1 & 13 & 15 & Turn on the fan \\
\hline 2 & 13 & 16 & Turn on the fan \\
\hline 3 & 14 & 14 & Turn on the fan \\
\hline 4 & 12 & 15 & Turn on the fan \\
\hline 5 & 13 & 14 & Turn on the fan \\
\hline 6 & 14 & 14 & Turn on the fan \\
\hline 7 & 13 & 12 & Turn on the fan \\
\hline 8 & 13 & 14 & Turn on the fan \\
\hline 9 & 20 & 14 & Turn on the fan \\
\hline 10 & 11 & 14 & Turn on the fan \\
\hline 11 & 9 & 14 & Turn on the fan \\
\hline 12 & 11 & 13 & Turn on the fan \\
\hline 13 & 12 & 15 & Turn on the fan \\
\hline 14 & 13 & 13 & Turn on the fan \\
\hline 15 & 15 & 13 & Turn on the fan \\
\hline 16 & 14 & 13 & Turn on the fan \\
\hline 17 & 13 & 13 & Turn on the fan \\
\hline 18 & 14 & 13 & Turn on the fan \\
\hline 19 & 15 & 13 & Turn on the fan \\
\hline 20 & 17 & 14 & Turn on the fan \\
\hline 21 & 10 & 13 & Turn on the fan \\
\hline 22 & 15 & 12 & Turn on the fan \\
\hline 23 & 15 & 12 & Turn on the fan \\
\hline 24 & 16 & 12 & Turn on the fan \\
\hline 25 & 16 & 11 & Turn on the fan \\
\hline 26 & 15 & 12 & Turn on the fan \\
\hline 27 & 15 & 11 & Turn on the fan \\
\hline 28 & 16 & 11 & Turn on the fan \\
\hline 29 & 16 & 11 & Turn on the fan \\
\hline 30 & 16 & 11 & Turn on the fan \\
\hline 31 & 16 & 12 & Turn on the fan \\
\hline 32 & 16 & 12 & Turn on the fan \\
\hline 33 & 16 & 10 & Turn on the fan \\
\hline 34 & 16 & 11 & Turn on the fan \\
\hline 35 & 15 & 12 & Turn on the fan \\
\hline 36 & 15 & 11 & Turn on the fan \\
\hline \multicolumn{3}{|c|}{ Total } & 93 \\
\hline
\end{tabular}




\begin{tabular}{|c|c|}
\hline Average error & 2,91667 \\
\hline Percentage of errors & 0,029 \\
\hline
\end{tabular}

The test was conducted by comparing the value of the vehicle when the fan in the condition of the dead and the vehicle when ignition fan. It aims to determine the control system run by good or not. The control system functions to control and maintain the air condition in the vehicle space. The test results of the tool as a whole can be seen in Table 2 .

\subsection{Fuzzy calculations}

The fuzzy calculation process starts from the process before and after the fan turns on. Vehicles before fan ignition $($ Input 1$)=9 \mathrm{ppm}$ and vehicles after fan ignition (Input 2) $=7.7 \mathrm{ppm}$, to calculate the $\mathrm{X}$ side with equations 4 and 5 .

Input 1

$\mu$ Safe $\mathrm{CO}=(10-\mathrm{X}) / 5$;

(4)

$$
\begin{aligned}
& =(10-9) / 5 ; \\
& =0.2
\end{aligned}
$$

$\mu \mathrm{CO}$ Alert $=(\mathrm{X}-8) / 6.5$

(5)

$$
\begin{aligned}
& =(9-8) / 6.5 \\
& =0.15
\end{aligned}
$$

Input 2

$$
\begin{aligned}
\mu \text { Safe CO } & =(8-X) / 4 \\
& =(8-7,7) / 4 \\
& =0.075 \\
\mu \text { CO Alert } & =(X-7.5) / 5.25 \\
& =(7,7-7,5) / 5,25 \\
& =0.038
\end{aligned}
$$

Furthermore, for $f$ unction i mplikasi used is the value of Min, so that the value of a turn off and turn on the fan as the results of equations 6 and 7 .

Turn off Fan $=$ Safe Input $1 \cap$ Safe Input 2

$=$ Min (Input 1 Safe [9] $\cap$ Input 2 Safe [7,7])

$$
\begin{aligned}
& =\operatorname{Min}(0.2 ; 0.075) \\
& =0.075
\end{aligned}
$$

Turn on Fan $=$ Safe Input $1 \cap$ Input 2 Alert

$=$ Min (Input 1 Safe [9] $\cap$ Input 2 Alert $[7,7])$

$$
\begin{aligned}
& =\operatorname{Min}(0.2 ; 0.038) \\
& =0.038
\end{aligned}
$$

Based on the results of the calculations turn off the fan and turn on the fan is taken the value of the highest and later on made in the form of curves image 3 and the results can be seen in equations 8 and 9 .

Turn on Fan $=$ Input 1 Alert $\cap$ Input 2 Safe

$=$ Min (Input 1 Alert [9] $\cap$ Input 2 Safe $[7,7])$ $=\operatorname{Min}(0.15 ; 0.075)$

$$
=0.075
$$

Turn On Fan = Input 1 Alert $\cap$ Input 2 Alert

$=$ Min (Input 1 Alert [9] $\cap$ Input 2 Alert $[7,7])$

$$
=\operatorname{Min}(0.15 ; 0.038)
$$

$$
=0.038
$$

\subsection{Calculation of defuzzyfication}

To get a firm value from the MOM (Mean of Maximum) method is to get the mean or middle value of the highest curve as in the equation 10 .

$$
X=(a+b) / 2(10)
$$

$a=10$ - turn off the fan $x 5 ; b=6.5+$ Turn on fan x 6.5

$$
\begin{aligned}
X & =((10-3.75)+(6.5+4,875)) / 2 \\
& =(6.25+11,375) / 2 \\
& =17,625 / 2=8.82 \text { (Result) }
\end{aligned}
$$

\section{CONCLUSION}

From the research that has been done it can be concluded that:

1. Control system for carbon monoxide gas levels in the car cabin based on fuzzy logic can work according to needs.

2. Before taking measurements, the sensor must be heated for approximately 20 seconds until the sensor can be used for measurement. Because the sensor cleans the remaining gas contained in the sensor, after that the voltage on the sensor is stable and measurements can be made.

\section{REFERENCES}

[1] S Syofian, S Guswan and Setiyaningsih T, “Detection system and security monitoring of the storage room of liquid oil gas with zoning method", https://iopscience.iop.org/article/10.1088/1757899X/909/1/012060

[2] A. Perdana, A. Fatchur Rochim, and E. Didik Widianto, "Purwarupa Sistem Pemantau dan Peringatan Kadar Gas Karbon Monoksida (CO) pada Kabin Mobil Berbasis Mikrokontroler ATMega8," J. Teknol. dan Sist. Komput., vol. 1, no. 2, p. 34, 2013.

[3] Y. T. Adi, "Pengaruh Usia Kendaraan Terhadap Emisi Karbon Monoksida (Co)P Dan Hidrokarbon (Hc) Kendaraan Bermotor Di Kota Bengkulu," 2012.

[4] S. Sinaga and D. S. Handayani, "Pengaruh Jumlah Kendaraan Dan Faktor Meteorologi Terhadap Konsentrasi Karbon Monoksida ( Co ) Di Jalan Pandanaran Kawasan Simpang Lima , Kota Semarang"

[5] Y. Yusrianti, "Studi Literatur tentang Pencemaran Udara Akibat Aktivitas Kendaraan Bermotor di Jalan Kota Surabaya," Al-Ard J. Tek. Lingkung., vol. 1, no. 1, pp. 11-20, 2015. 